\title{
Benefits of Legume Crops in Rotation and Intercropping for Increased Production and Land Use
}

\author{
M.A. Abou-Keriasha, Nadia M.A. Eisa and M.M. Lamlom \\ Crop Intensification Res. Sec., Field Crops Res. Inst., Agric. \\ Res. Center, Giza, Egypt.
}

\begin{abstract}
7 HIS STUDY was carried out at Mallawi Agric. Res. St. during the two seasons of 2011/2012 and 2012/2013 to study the effect of preceding winter crops (wheat, wheat + fahl berseem, faba bean + onion or berseem) and intercropping maize with cowpea on production and land use. A split plots design with three replications was used. The results showed that maize, cowpea and associated weeds were significantly affected by both preceding winter crops and intercropping system. Planting maize after legume crops (faba bean + onion or berseem) produced the highest values of maize yield and yield components. While maize grown after wheat had the lowest values. Increase of maize grain yield was $8.0 \%$, after faba bean + onion, while increase after wheat + fahl berseem was $1.4 \%$ as compared with those grown after wheat. The weed density in maize grown after berseem was reduced by $44.0 \%$ as compared with that grown after wheat.
\end{abstract}

The yield and yield components of maize were increased when intercropped with cowpea. The increased in grain yield was $2.5 \%$, while forage green yield of intercropped cowpea was reduced by $67 \%$ compared to solid planting. Weeds density in intercropped maize was reduced (59\%) compared with solid planting.

The highest values of LER (1.35) were observed when was the winter crop wheat. The highest values of the intensification index (2.64) were observed by the crop sequence faba bean + onion / maize +cowpea. The crop sequence berseem / maize + cowpea recorded the highest values of cereal unit, while the crop sequence wheat + fahl berseem / maize + cowpea had the highest values for total revenue and net return. It is concluded that the preceding legume crops had a large effect on maize yield and a small effect on weed density. Intercropping maize with cowpea had a large effect on weed density.

Keywords: Maize, Cowpea, Crop sequence, Intercropping.

In cereal - legume rotation or intercropping systems the cereal benefits from the nitrogen fixed by the legume crops and from the decomposition of nutrient rich biomass from root; and nodules of the legume, therefore, the increased yield of maize may be attributed to nitrogen fixing ability of legumes (Chen et al., 2004), helping to increase soil organic matter (Gregrich et al., 2001), and reduce weed population density (Liebman \& Dyck, 1993). 
Several researchers reported the cereal yields superiority after legume crops has been attributed to increases in residual organic matter as compared cereal grown after non legume crops (Mac Coll, 1991 and Abou-Keriasha et al., 1998). Ahlawet et al. (1981) showed that preceding grain legumes increased mean plant height, length and diameter of cob, grain yield /cob and 1000 grains of maize compared with wheat and fallow.

Crop sequence helps to reduce weed population by interrupting their life cycle and suppressing their growth development and dispersion. Shafshak et al. (1983) found that maize after clover contained $76 \%$ of the total fresh weight of weeds in maize after wheat.

Several researchers on intercropping systems noted that yield of one or all of the crops in the intercrop were lower than that of the total of the pure stands. The reduction in intercropped maize yield ranged from a small reduction of $15 \%$ of pure stand compared with a greater reduction ranging from $45 \%$ to 67 $\%$ in legume crops (Fininsa, 1997). Whereas, Khan et al. (2002) and AbouKeriasha et al. (2011) showed that cereal grain yield was increased by intercropping compared with solid. Abou-Keriasha et al. (2009) found that the highest land equivalent ratio (LER) recorded was 1.29 and the monetary L.E. was 1874.52. Similar results were published by Khan et al. (2002).

Intercropping can also reduce the density of the weeds associated with maize (Hollander et al., 2007). Zougmore et al. (2000) showed that sorghum + cowpea intercrops reduced weeds by 20-30\% compared to solid. Abou-Keriasha et al. (2011) found that intercropping cowpea on maize and sorghum reduced weed biomass by 77 and $86 \%$ compared with solid plots, respectively. Abou-Keriasha et al. (2012) noted that inclusion of legumes in rotation and intercropping systems increased productive of cereal crops and reduced weeds. The objective of this investigation was to compare the legume crops as preceding or in an intercropping system on maize grain yield and land use.

\section{Materials and Methods}

Two fields experimental were carried out at Mallawi Agric. Res. St. (Middle Egypt) during two seasons of 2011/2012 and 2012/2013. Mallawi Experiment Station Site (27" 4355 N, 30" 5028 E, 27 m a.s.l.) is located $300 \mathrm{~km}$ far south of Cairo the capital. Climate in this region is dry hot in summer with max. 36 and min. $15 \mathrm{C}^{\circ}$ and cold in winter with max. 17 and min $5 \mathrm{C}^{\circ}$. The soil of the site is clay loam with $\mathrm{pH}$ 7.6-8.5 and medium inherit fertility. The objective of this investigation was to study the effect of preceding winter crop and intercropping maize + cowpea on yield, and yield components of maize + cowpea and land use. A Randomized Complete Block Design (RCBD) in a spilt plot with three replications was used. The four winter crops (wheat 'c.v. Giza 168', wheat + fahl berseem, faba bean 'c.v. Giza 843' + onion 'c.v. Giza 6' and berseem c.v. Miskawi) were grown as the preceding crop. In the two summer seasons (2012 and 2013), maize (T.W.C. 310) was grown in the same plots as

Egypt. J. Agron. 35, No. 2 (2013) 
the second crop. The winter crops were allocated to the main plots, while the summer cropping system (solid maize and intercropped maize with cowpea c.v. Cream) were arranged in sub plots. The sub plot area was $10.5 \mathrm{~m}^{2}$, containing 5 ridges, each $3.0 \mathrm{~m}$ long and $0.70 \mathrm{~m}$ wide $(1 / 400$ fed.). Planting and harvesting dates of crops are presented in Table 1.

TABLE 1. Planting and harvest dates of field crops.

\begin{tabular}{|c|c|c|c|c|}
\hline \multirow{2}{*}{$\begin{array}{l}\text { Cropping system } \\
\text { Winter crop }\end{array}$} & \multicolumn{2}{|c|}{ First season $(2011 / 2012)$} & \multicolumn{2}{|c|}{$\begin{array}{c}\text { Second season } \\
(2012 / 2013)\end{array}$} \\
\hline & $\begin{array}{c}\text { Planting } \\
\text { date }\end{array}$ & $\begin{array}{c}\text { Harvest } \\
\text { date }\end{array}$ & $\begin{array}{c}\text { Planting } \\
\text { date }\end{array}$ & $\begin{array}{c}\text { Harvest } \\
\text { date }\end{array}$ \\
\hline Solid wheat & $15 / 11$ & $10 / 5$ & $22 / 11$ & $5 / 5$ \\
\hline Wheat + berseem (mixture) & $15 / 11$ & $10 / 5$ & $22 / 11$ & $5 / 5$ \\
\hline $\begin{array}{l}\text { Faba bean + onion } \\
\text { (intercrop) }\end{array}$ & $\begin{array}{l}25 / 10 \\
15 / 11 *\end{array}$ & $\begin{array}{l}22 / 4 \\
10 / 5\end{array}$ & $\begin{array}{l}22 / 10 \\
11 / 11\end{array}$ & $\begin{array}{l}28 / 4 \\
15 / 5\end{array}$ \\
\hline Berseem (Messcawi) & \multirow{2}{*}{$25 / 10$} & \multirow{2}{*}{$\begin{array}{l}* * \\
* *\end{array}$} & \multirow{2}{*}{$22 / 10$} & $* *$ \\
\hline Summer crops & & & & $* *$ \\
\hline Solid maize & $25 / 5$ & $15 / 10$ & $8 / 6$ & $10 / 10$ \\
\hline Intercropped maize & $25 / 5$ & $15 / 10$ & $8 / 6$ & $10 / 10$ \\
\hline Solid cowpea(forage) & $15 / 6$ & $\begin{array}{l}15 / 8 \\
15 / 9 \\
\end{array}$ & $28 / 6$ & $\begin{array}{l}28 / 8 \\
5 / 10 \\
\end{array}$ \\
\hline Intercropped cowpea & $15 / 6$ & $15 / 8$ & $28 / 6$ & $25 / 8$ \\
\hline
\end{tabular}

Transplanting onion plants.

*** Data of four cuts after 60, 115, 145 and 175 days from sowing.

Maize (solid or intercrop) was grown on one side of the ridge with one plant /hill, $(30 \times 70 \mathrm{~cm})$. Intercropped cowpea was sown on the other side of maize ridges with two plants /hill $20 \mathrm{~cm}$ apart $(20 \times 70 \mathrm{~cm})$. Solid cowpea as comparison and to estimate competitive relationship was grown on one side of ridges with two plants /hill, $20 \mathrm{~cm}$ apart and $70 \mathrm{~cm}$ width.

Calcium super phosphate $\left(15.5 \% \mathrm{P}_{2} \mathrm{O}_{5}\right)$ at the rate of $30 \mathrm{~kg} \mathrm{P}_{2} \mathrm{O}_{5} /$ fed. and potassium fertilizer (potassium sulfate $48.5 \% \mathrm{~K}_{2} \mathrm{O}$ ) at a rate $24 \mathrm{~kg} \mathrm{~K}_{2} \mathrm{O} / \mathrm{fed}$ were added during preparations. Nitrogen, as ammonium nitrate $(33.5 \% \mathrm{~N})$, at the rate of $120 \mathrm{~kg} \mathrm{~N} / \mathrm{fed}$., was added in three equal portions just before the first ,second and third irrigation of maize. Nitrogen fertilizer for cowpea was added before first irrigation at the rate of $20 \mathrm{~kg} \mathrm{~N} / \mathrm{fed}$.

The winter crops were managed using normal cultural practices in the district. Faba bean + onion was sown on ridges $120 \mathrm{~cm}$ wide in four rows and faba bean on the bed while the onion was transplanted at two months age on the two sides of all ridges $15 \mathrm{~cm}$ apart. Mixed wheat + fahl berseem, $(5 \mathrm{~kg}$ fahl berseem $+35 \mathrm{~kg}$ wheat/ fed) was sown in rows $(20 \mathrm{~cm})$. At maturity, winter crops were hand harvested and estimated the yields of each crop (Table 2). 
TABLE 2. Grain and seed yield/fed of preceding winter crops in both seasons.

\begin{tabular}{|l|c|c|}
\hline \multicolumn{1}{|c|}{ Winter crop } & First season (2011/2012) & Second season (2012/2013) \\
\hline \multirow{2}{*}{ Wheat } & 18.5 ardab (grain) & 17.7 ardab (grain) \\
& 4.320 ton (straw) & 4.250 ton (straw) \\
\hline \multirow{2}{*}{ Wheat $+\mathrm{F}}$, & 18.65 ardab of wheat(grain) & 18.85 ardab of \\
berseem & $22 \mathrm{~kg}$ seed of F, berseem & $21 \mathrm{~kg}$ seed of F, berseem \\
& 3.800 ton straw & 3.850 ton straw \\
\hline \multirow{2}{*}{ F, bean + onion } & 7.2 ardab faba bean seed & 5.8 ardab faba bean seed \\
& 1.575 ton straw & 1.600 ton straw \\
& 5.6 ton onion & 4.8 ton onion \\
\hline Berseem & 31 ton green fodder & 28 ton green fodder \\
\hline
\end{tabular}

$1 \mathrm{fed}=0.42$ ha

First cut of cowpea (solid or intercrop) was done two months after sowing and the second cut was done in solid only two months after first cut.

At harvest, three maize plants were chosen randomly from each sub plot to determine plant height, ear height, number of kernels/row, weight of grains /ear, number of ears/plant and shelling percentage. Grain yield of maize (ardab /fed, $. \operatorname{ardab}=140 \mathrm{~kg}$ ), and green forage yield of cowpea were estimated from the whole sub plot area (kg plot) and it was calculated per fed. Weeds were hand pulled from one square meter for each sub plot before first and second hoeing (hand hoeing was done twice, 30 and 45 days after sowing of cowpea).

Competitive relationships and yield advantage

Land equivalent ratio (LER)

LER is determined as the sum of the fractions of the yield of intercrops relative to their sole crop yield (Willey \& Osira, 1972), as follows for maize + cowpea:

where

$$
\mathrm{LER}=\frac{\mathrm{Y}_{\mathrm{ab}}}{\mathrm{Y}_{\mathrm{aa}}}+\frac{\mathrm{Y}_{\mathrm{ba}}}{\mathrm{Y}_{\mathrm{bb}}}
$$

$\mathrm{Y}_{\mathrm{aa}}=$ Yield of maize in pure stand.

$\mathrm{Y}_{\mathrm{bb}}=$ Yield of cowpea in pure stand.

$\mathrm{Y}_{\mathrm{ab}}=$ Yield of maize intercropped with cowpea.

$\mathrm{Y}_{\mathrm{ba}}=$ Yield of cowpea intercropped with maize.

Competitive ratio $(C R)$

The CR index was calculated using the following formula as advocated by Willey \& Rao (1980).

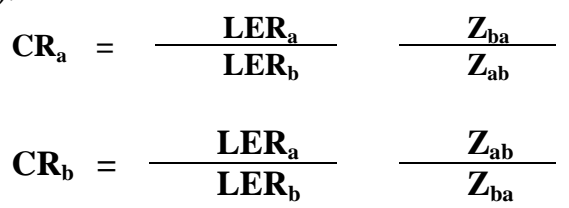

Egypt. J. Agron. 35, No. 2 (2013) 
where: $\mathrm{LER}_{\mathrm{a}}$ and $\mathrm{LER}_{\mathrm{b}}$

represent relative yield of $\mathrm{a}$ and $\mathrm{b}$ intercrops, respectively.

Since the CR values of the two crops will in fact be the reciprocals of each other. $\mathrm{CR}_{\mathrm{a}}, \mathrm{CR}_{\mathrm{b}}$ are the competitive ratio for intercrop where $\mathrm{Z}_{\mathrm{ab}}$ representing the sown proportion of intercrop a (legume crops) in combination with $b$ (maize) and $\mathrm{Z}_{\mathrm{ba}}$ the sown proportion of intercrop maize in combination with a legume crop .

\section{Farmer's benefit}

Intensification index

The intensification index was calculated as following formula.

$$
\left.=\sum[\text { (crop area }) /(\text { land area })\right]
$$

$=$ number of crops grown during one year / the cultivated area

\section{Cereal unit}

The yield of all crops was converted to cereal units according to Brockaus (1962) for judicious comparison. One hundred $\mathrm{kg}$ of each crop or crop part was allocated: maize and wheat $=1$ unit, berseem $=0.14$, cowpea $=0.12$, faba bean seeds $=1.2$, onion $=0.30$, cereal straw $=0.10$ and legume straw $=0.25$.

\section{Economic evaluation}

Net return was calculated according to Agricultural Statistics (2010), the average market price was as follow: 2473.3 L.E./ton wheat, 2142.85 L.E./ton maize, 3225.80 L.E. /ton faba bean, 600 L.E./ ton onion, 1222 L.E./ ton cut of berseem, 150 L.E./ ton cowpea, 350 L.E./ ton cereal straw and 250 L.E./ ton faba bean straw.

Total costs (rent + total variable cost) were as follow 2800L.E./ ton maize, 2500 L.E./ ton wheat. 2300 L.E./ faba bean, 1200 L.E./ berseem, 2800 L.E./ onion and 300 L.E./ cowpea.

Data of the two seasons were analyzed by MSTATC (1980) software to comprise the mean values of the two seasons and the combined by LSD test at the 5\% level according by Snedecor \& Cochran (1988).

Maize

\section{Results and Discussion}

Preceding winter crop effects

Results in Table 3 indicate that these were significant effects of preceding winter crop (wheat, wheat + fahl berseem, faba bean + onion or berseem) on maize yield, yield components and associated weeds, expect plant height in both seasons and shelling percentage in the second season. Maize plants preceded by the legume crop (faba bean + onion or berseem) were taller than those preceding wheat in both seasons. The ear height character followed the same trend. Maize preceded by faba bean + onion was superior in most yield 
components (no. of kernels /row, wt. of 100 kernels, no. of ears/plant and wt. of kernels /ear) in both seasons. Also maize grown after wheat + fahl berseem recorded the height values of all characters as compared with those grown after wheat in both seasons. The superiority may be attributed to the high level of soil fertility, due to nitrogen fixation and decomposition of crop residues after legume crop (faba bean or berseem). The results are in agreement with those obtained by Mac Coll (1991).

TABLE 3. Preceding winter crop effects on yield, yield components of maize and associated weeds during the two seasons and combined of the two seasons.

\begin{tabular}{|c|c|c|c|c|c|c|c|c|c|}
\hline Preceding & $\begin{array}{c}\text { Plant } \\
\text { height } \\
(\mathrm{cm})\end{array}$ & $\begin{array}{c}\text { Ear } \\
\text { height } \\
(\mathbf{c m})\end{array}$ & $\begin{array}{c}\text { Kernels } \\
\text { /row } \\
\text { (no) }\end{array}$ & $\begin{array}{c}\text { Kernels } \\
\text { /ear } \\
(\mathrm{gm})\end{array}$ & $\begin{array}{c}\text { Ears/ } \\
\text { plant } \\
\text { (no) }\end{array}$ & $\begin{array}{c}100 \\
\text { Kernels } \\
(\mathrm{gm})\end{array}$ & $\begin{array}{c}\text { Shelling } \\
(\%)\end{array}$ & $\begin{array}{c}\text { Grain } \\
\text { yield/fed } \\
\text { (ardab) }\end{array}$ & $\begin{array}{l}\text { Weeds } \\
\text { gm/ } / \mathbf{m}^{2}\end{array}$ \\
\hline Wint & \multicolumn{9}{|c|}{ First season } \\
\hline Wheat & 284.33 & 170.50 & 44.33 & 233.33 & 1.07 & 35.6 & 83.47 & 22.52 & 622.17 \\
\hline $\begin{array}{l}\text { Wheat + F, } \\
\text { berseem }\end{array}$ & 284.50 & 176.00 & 48.16 & 243.00 & 1.08 & 36.2 & 84.12 & 22.70 & 620.00 \\
\hline $\begin{array}{l}\text { Faba bean }+ \\
\text { Onion }\end{array}$ & 286.50 & 177.00 & 50.64 & 249.16 & 1.13 & 40.2 & 85.00 & 24.35 & 412.00 \\
\hline Berseem & 285.83 & 177.33 & 48.50 & 244.16 & 1.11 & 39.7 & 85.67 & 23.53 & 339.00 \\
\hline \multirow[t]{2}{*}{ LSD $5 \%$} & NS & 3.16 & 1.53 & 6.04 & 0.03 & 0.24 & 1.25 & 0.54 & 10.8 \\
\hline & \multicolumn{9}{|c|}{ Second season } \\
\hline Wheat & 281.00 & 170.17 & 43.66 & 229.16 & 1.06 & 35.5 & 82.97 & 21.10 & 660.17 \\
\hline $\begin{array}{l}\text { Wheat + F, } \\
\text { berseem }\end{array}$ & 281.87 & 174.50 & 48.00 & 235.60 & 1.09 & 36.6 & 83.00 & 21.70 & 646.67 \\
\hline $\mathrm{F}$, bean + Onion & 283.67 & 176.50 & 51.08 & 246.83 & 1.11 & 39.0 & 84.00 & 23.52 & 433.33 \\
\hline Berseem & 285.67 & 178.83 & 49.65 & 245.00 & 1.09 & 38.9 & 84.83 & 23.45 & 371.33 \\
\hline \multirow[t]{2}{*}{ LSD $5 \%$} & NS & 4.01 & 1.07 & 4.56 & 0.04 & 0.48 & NS & 0.84 & 9.9 \\
\hline & \multicolumn{9}{|c|}{ Combined of the two seasons } \\
\hline Wheat & 282.66 & 170.33 & 44.00 & 231.74 & 1.06 & 35.50 & 83.22 & 21.81 & 641.12 \\
\hline $\begin{array}{l}\text { Wheat }+F \text {, } \\
\text { berseem }\end{array}$ & 283.18 & 175.25 & 48.10 & 239.30 & 1.08 & 36.40 & 83.56 & 22.20 & 633.33 \\
\hline $\mathrm{F}$, bean + Onion & 285.08 & 176.75 & 50.85 & 248.00 & 1.12 & 39.60 & 84.50 & 24.00 & 422.66 \\
\hline Berseem & 285.75 & 178.10 & 49.10 & 244.60 & 1.10 & 39.30 & 85.25 & 23.50 & 355.16 \\
\hline LSD $5 \%$ & N.S. & 3.71 & 2.01 & 6.10 & 0.03 & 0.55 & 1.56 & 0.61 & 13.35 \\
\hline
\end{tabular}

Ear height: height above ground

Shelling percentage: weight of kernels of ear/weight of ear (cob + kernels)

Egypt. J. Agron. 35, No. 2 (2013) 
Maize sown after faba bean + onion resulted in an increase of $15.6 \%$ for no. of kernels /row, $11.4 \%$ for wt. of 100 kernels, $7.2 \%$ for wt. of kernels $5.1 \%$ for no. of ears/plant and $1.6 \%$ for shelling percentage, while maize grown after wheat + fahl berseem recorded an increase of $4.8 \%$ for no. of kernels /row, $2.4 \%$ for wt. of 100 kernels, $0.02 \%$ for no. of ears/plant and 3.3\% for weight of kernels /ear as compared with those grown after wheat. The yield of maize grain grown after faba bean + onion outyielded by $8.0 \%$ compared maize after wheat (combined). Grain yield of maize grown after wheat + fahl berseem recorded an increase of $1.4 \%$ compared with maize grown after wheat (combined). Similar results are obtained by Ahlawet et al. (1981).

The results also show that the fresh weight of associated weeds (Corohrus olitorins, Portulaca oleracea, Xanthium strumarium and Panicum sp), was significantly affected by preceding winter crop. Weed density in maize preceded by berseem or by faba bean + onion was least as compared to that after wheat or wheat + fahl berseem. Reductions in weed density when maize was grown after berseem was $44.0 \%$, while, when grown after faba bean + onion, it was $33.3 \%$ compared with when grown after wheat. Crop sequence can provide an unfavorable environment for weed, by varying resources, competition, allelopathic interference, soil disturbance or mechanical damage. These results are in agreement with the obtained by Zougmore et al. (2000).

Intercropping effects

Results in Table 4 show significant differences in all studied characters except no. of kernels/ear, no. of ears/plant, shelling percentage and grain yield/fed. The results indicate that intercropping system resulted in taller maize plants than in solid planting. The ear height followed the same trend. Also, the results proved that the yield and yield components of maize intercropped with cowpea were increased as compared with solid planting. These increases were $2.3 \%$ for number of kernels/row, $2.7 \%$ for weight of kernels/ear, $2.3 \%$ for number of ears/plant, $6.1 \%$ for weight of 100 kernels and $2.2 \%$ for grain yield, clearly showing legume crops intercropped with cereal crops. Similar results were obtained by Ahlawet et al. (1981) and Zohry (2005).

The results show also that intercropping had significant effects on weeds weight. The weight of associated weeds was reduced by intercropping $(59.8 \%)$ compared to solid planting. Thus in the maize + cowpea intercrop this reduction is due to less available light for weeds leading to a reduction in weed density and dry matter compared to solid planting (Liebman \& Dyck, 1993).

\section{Interaction effects}

There were significant differences in most studied characters of maize as affected by interaction between preceding winter crops and cropping system (Table 5). The highest values of yield and yield components (no. of kernels / row, weight of kernels /ear, weight of 100 kernels and grain yield /fed) when intercropping with cowpea and preceded by faba bean+onion, while the lowest values of these characters were observed in solid planting and preceded with 
wheat in both seasons. The values of yield and yield components in solid maize and grown after legume crops (berseem or faba bean) were higher than those intercropping with cowpea and proceeded by cereal crops (wheat). The increasing in grain yield of solid maize and grown after legume crops was ranged from 1.10 to $1.45 \mathrm{ardab} /$ fad over those grown after cereal crops (wheat) and intercropping with cowpea.

TABLE 4. Cropping systems effects on yield, yield components of maize and associated weeds during the two seasons and combined of the two seasons.

\begin{tabular}{|c|c|c|c|c|c|c|c|c|c|}
\hline Traits & $\begin{array}{c}\text { Plant } \\
\text { height } \\
(\mathrm{cm})\end{array}$ & $\begin{array}{c}\text { Ear } \\
\text { height } \\
(\mathrm{cm})\end{array}$ & $\begin{array}{c}\text { Kernels/ } \\
\text { row } \\
\text { (no) }\end{array}$ & $\begin{array}{c}\text { Kernels } \\
\text { /ear } \\
(\mathrm{gm})\end{array}$ & $\begin{array}{c}\text { Ears/ } \\
\text { plant } \\
\text { (no) }\end{array}$ & $\begin{array}{c}100 \\
\text { kernels } \\
(\mathrm{gm})\end{array}$ & $\begin{array}{c}\text { Shelling } \\
(\%)\end{array}$ & $\begin{array}{c}\text { Grain } \\
\text { yield/fed. } \\
\text { (ardab) }\end{array}$ & $\begin{array}{c}\text { Weeds } \\
\left(\mathrm{gm} / \mathrm{m}^{2}\right)\end{array}$ \\
\hline rea & \multicolumn{9}{|c|}{ First season } \\
\hline Solid & 283.42 & 171.85 & 47.25 & 240.41 & 1.09 & 36.9 & 84.25 & 23.14 & 710.25 \\
\hline Intercropping & 287.17 & 178.58 & 48.58 & 244.41 & 1.11 & 39.0 & 84.88 & 23.43 & 286.33 \\
\hline \multirow[t]{2}{*}{ LSD 5\% } & 1.13 & 1.39 & NS & 2.15 & NS & 0.62 & NS & NS & 12.1 \\
\hline & \multicolumn{9}{|c|}{ Second season } \\
\hline Solid & 279.50 & 171.92 & 47.29 & 234.58 & 1.07 & 36.30 & 83.17 & 22.07 & \begin{tabular}{|l|}
753.75 \\
\end{tabular} \\
\hline Intercropping & 286.58 & 178.08 & 48.83 & 243.49 & 1.10 & 38.7 & 83.67 & 22.79 & 302.00 \\
\hline \multirow[t]{2}{*}{ LSD 5\% } & 1.20 & 2.23 & NS & 7.25 & NS & 0.40 & NS & NS & 19.0 \\
\hline & \multicolumn{9}{|c|}{ Combined of the two seasons } \\
\hline Solid & 281.46 & 171.88 & 47.27 & 237.49 & 1.08 & 36.75 & 83.71 & 22.60 & 732.00 \\
\hline Intercropping & 286.81 & 178.33 & 48.70 & 244.00 & 1.10 & 38.85 & 84.27 & 23.11 & 294.16 \\
\hline LSD $5 \%$ & 1.80 & 2.90 & N.S. & 7.14 & N.S. & 1.00 & N.S. & N.S. & 19.50 \\
\hline
\end{tabular}

Ear height: height above ground

Shelling percentage: weight of kernels of ear/weight of ear (cob + kernels)

These results indicate that maize grown after faba bean or berseem (legume crops) has more beneficial effect on yield and yield components than intercropping with cowpea. Similar results were obtained by Khan et al. (2002).

The results show also the highest values of weed weight $\left(893.76 \mathrm{gm} / \mathrm{m}^{2}\right)$ were observed in solid planting and preceded by wheat. The lowest value was recorded in intercropped maize with cowpea and sequence by berseem or faba bean + onion. It is clear that the effect of intercropping maize with cowpea on weed density is higher than the effect of the preceding winter crop. Similar results were obtained by Hollander et al. (2007).

\section{Cowpea}

Results presented in Table 6 show that green forage yield of intercropped cowpea was affected by preceding crops. The highest yield o $\mathrm{f}$ green forage (4.4 ton/fed) was observed when cowpea intercropped on maize ridges was preceded by wheat, while, the lowest values $(3.5$ ton/fed) was observed in intercropped cowpea on maize ridges after faba bean + onion. 
BENEFITS OF LEGUME CROPS IN ROTATION...

TABLE 5. Effect of preceding crop and cropping system on yield, yield component of maize and associated weeds (combined of the two seasons).

\begin{tabular}{|c|c|c|c|c|c|c|c|}
\hline \multicolumn{2}{|c|}{ Treatment } & \multirow{2}{*}{$\begin{array}{c}\begin{array}{c}\text { Ear height } \\
\text { (cm) }\end{array} \\
166.50\end{array}$} & \multirow{2}{*}{$\begin{array}{c}\begin{array}{c}\text { Kernels/ } \\
\text { row } \\
\text { (no) }\end{array} \\
41.72\end{array}$} & \multirow{2}{*}{$\begin{array}{c}\begin{array}{c}\text { Kernels/ear } \\
\text { (gm) }\end{array} \\
227.50\end{array}$} & \multirow{2}{*}{$\begin{array}{c}\begin{array}{c}\text { Wt. 100- } \\
\text { kernel } \\
\text { (gm) }\end{array} \\
35.10\end{array}$} & \multirow{2}{*}{$\begin{array}{c}\begin{array}{c}\text { Grain yield } \\
\text { /fed. } \\
\text { (ardab) }\end{array} \\
21.20\end{array}$} & \multirow{2}{*}{$\begin{array}{r}\begin{array}{r}\text { Weeds } \\
\left(\mathbf{g m} / \mathbf{m}^{2}\right)\end{array} \\
893.66\end{array}$} \\
\hline Whent & Solid & & & & & & \\
\hline & $\begin{array}{c}\text { Inter- } \\
\text { cropping }\end{array}$ & 174.16 & 46.00 & 235.00 & 36.00 & 22.35 & 388.66 \\
\hline \multirow{2}{*}{$\begin{array}{c}\text { Wheat } \\
+ \text { Fahl } \\
\text { berseem }\end{array}$} & Solid & 173.50 & 47.66 & 234.16 & 35.50 & 22.00 & 878.33 \\
\hline & $\begin{array}{c}\text { Inter- } \\
\text { cropping }\end{array}$ & 177.0 & 48.50 & 243.83 & 37.35 & 22.47 & 388.33 \\
\hline \multirow{2}{*}{$\begin{array}{l}\text { Faba } \\
\text { bean } \\
+ \text { onion }\end{array}$} & Solid & 172.83 & 50.74 & 243.33 & 38.30 & 23.80 & 646.16 \\
\hline & $\begin{array}{c}\text { Inter- } \\
\text { cropping }\end{array}$ & 180.63 & 51.00 & 252.66 & 40.90 & 24.10 & 199.17 \\
\hline \multirow{2}{*}{ Berseem } & Solid & 174.66 & 48.66 & 242.50 & 37.55 & 23.46 & 509.83 \\
\hline & $\begin{array}{c}\text { Inter- } \\
\text { cropping }\end{array}$ & 181.50 & 49.33 & 246.66 & 41.10 & 23.50 & 200.50 \\
\hline \multicolumn{2}{|l|}{ LSD 5\% } & 3.25 & 5.36 & 12.15 & 1.05 & 1.25 & 41.56 \\
\hline
\end{tabular}

Ear height: height above ground

TABLE 6. Preceding winter crops and intercropping systems effects on green forage yield of cowpea during the two seasons and average of the two seasons.

\begin{tabular}{|l|c|c|c|}
\hline Preceding crops & $\begin{array}{c}\text { First season } \\
\text { (ton/fed) }\end{array}$ & $\begin{array}{c}\text { Second season } \\
\text { (ton/fed) }\end{array}$ & $\begin{array}{c}\text { Combined of the } \\
\text { two seasons } \\
\text { (ton/fed) }\end{array}$ \\
\hline Wheat & 4.5 & 4.3 & 4.4 \\
\hline $\begin{array}{l}\text { bheat Ferseem } \\
\text { Faba bean + onion }\end{array}$ & 4.3 & 4.1 & 4.2 \\
\hline Fahl berseem & 3.5 & 3.6 & 3.5 \\
\hline LSD 5\% & 3.8 & 3.8 & 3.8 \\
\hline solid & 0.34 & 0.25 & 0.30 \\
\hline
\end{tabular}

The results also showed that green forage of cowpea yield was reduced under intercropping system as compared with solid planting. The reduction in green forage was $70.0 \%$ after wheat and $76.0 \%$ after berseem. This reduction in green forage might be due to more shading effect of taller maize plants on shorter cowpea plants and adverse effect of shading. Similar results were obtained by Hollander et al. (2007) and Abou-Keriasha et al. (2011). 
Competitive relationships and yield advantages

Land equivalent ratio (LER)

Results in Table 7 indicate that land equivalent ratio (LER) and competitive ratio (CR) varied considerably due to the effect of the preceding winter crop during the two seasons. Results reveal that yield of maize was increased in all cases expect when preceded by berseem, while that of intercropped cowpea was decreased in all cases in both seasons. The highest values of $R Y_{m}$ (1.05) were observed when growing maize after wheat and the lowest values (1.00) were observed after berseem; whereas the highest values of $R Y_{c}(0.30)$ were observed when grown after wheat, and the lowest values (0.24) were observed when grown after faba bean + onion.

TABLE 7. Preceding crops effects on competitive relationship and yield advantages of intercropping maize and cowpea during the two seasons.

\begin{tabular}{|l|c|c|c|c|c|}
\hline \multirow{2}{*}{ Preceding crop } & \multicolumn{3}{|c|}{ LER } & \multicolumn{2}{c|}{ CR } \\
\cline { 2 - 6 } & $\mathbf{R Y}_{\mathbf{m}}$ & $\mathbf{R Y}_{\mathbf{c}}$ & Total & $\mathbf{C R}_{\mathbf{m}}$ & $\mathbf{C R}_{\mathbf{c}}$ \\
\hline Wheat & 1.05 & 0.30 & 1.35 & 3.51 & 0.28 \\
\hline $\begin{array}{l}\text { Wheat + Fahl } \\
\text { berseem }\end{array}$ & 1.02 & 0.28 & 1.30 & 3.64 & 0.27 \\
\hline $\begin{array}{l}\text { Faba bean + } \\
\text { onion }\end{array}$ & 1.01 & 0.24 & 1.25 & 4.36 & 0.24 \\
\hline Berseem & 1.00 & 0.25 & 1.25 & 3.93 & 0.25 \\
\hline
\end{tabular}

$\mathrm{RY}_{\mathrm{m}}=\mathrm{LER}_{\text {maize }}$

$\mathrm{RY}_{\mathrm{c}}=\mathrm{LER}_{\text {cowpea }}$

Land equivalent ratio (LER) values were greater than one. It could be concluded that the actual productivety was higher than the expected productivity. The highest LER value (1.35) was observed after wheat, while the lowest value (1.25) were observed after faba bean + onion.

\section{Competitive ratio $(C R)$}

Results on competitive ratio (CR) clear that competition ratio of maize $\left(\mathrm{CR}_{\mathrm{m}}\right)$ were greatest than competition ratio of cowpea $\left(\mathrm{CR}_{\mathrm{c}}\right)$ which expresses the exact degree of competitive indicates that the main crop (maize) was more competitive than cowpea (the dominance of maize on cowpea). The competitive degree of maize was increased when preceded by legume crops (faba bean + onion or berseem) as compared with those preceded by cereal crops. The competitive degree of cowpea was decreased when grown after legumes as compared with those grown after cereal crops.

\section{Farmer's benefit}

Preceding crop and intercropping effect on intensification index

Results in Table (8) show that the preceding crop and cropping system had appreciable effects on the intensification index value. Crop sequences faba bean + onion/ maize + cowpea had increase in the intensification index by $15.4 \%$ followed by the crop sequence, wheat + fahl berseem / maize + cowpea $(5.0 \%)$ as compared with crop sequence wheat / maize (combined of the two seasons). Also, intercropping cowpea with maize resulted in an increase in the value of

Egypt. J. Agron. 35, No. 2 (2013) 
the intensification index by $13.5 \%$ compared with solid maize. The highest value (2.63) was observed in the crop sequence, faba bean+ onion/ maize + cowpea, while the lowest value (2.0) was observed in the crop sequence wheat / maize. Similar results were obtained by Chen et al. (2004), Gregrich (2001) and Abou-Keriasha et al. (2012).

TABLE 8. Intensification index value and cereal unit for each crop sequence.

\begin{tabular}{|c|c|c|c|}
\hline \multicolumn{2}{|c|}{ Crop sequence } & \multirow{2}{*}{ Intensification index } & \multirow[b]{2}{*}{ Cereal unit } \\
\hline $\begin{array}{l}\text { Preceding } \\
\text { crops }\end{array}$ & $\begin{array}{c}\text { Cropping } \\
\text { system }\end{array}$ & & \\
\hline \multirow{3}{*}{ Wheat } & Solid maize & 2.00 & 61.25 \\
\hline & Maize +cowpea & 2.35 & 66.03 \\
\hline & Mean & 2.17 & 63.64 \\
\hline \multirow{3}{*}{$\begin{array}{l}\text { Wheat } \\
\text { berseem }\end{array}$} & Solid maize & 2.13 & 64.86 \\
\hline & Maize +cowpea & 2.44 & 69.83 \\
\hline & Mean & 2.28 & 67.34 \\
\hline \multirow{3}{*}{$\begin{array}{l}\text { Faba } \\
\text { Onion }\end{array}$} & Solid maize & 2.54 & 66.25 \\
\hline & Maize +cowpea & 2.63 & 66.42 \\
\hline & Mean & 2.58 & 66.33 \\
\hline \multirow{3}{*}{ Berseem } & Solid maize & 2.06 & 88.05 \\
\hline & Maize +cowpea & 2.35 & 92.60 \\
\hline & Mean & 2.20 & 90.32 \\
\hline \multirow[b]{2}{*}{ Mean of all crops } & Solid maize & 2.14 & 69.50 \\
\hline & Maize + cowpea & 2.43 & 73.11 \\
\hline
\end{tabular}

Preceding crop and intercropping effect on cereal unit

Results in Table 8 show also that the average cereal unit varied according to preceding crop and intercropping system. The cereal unit values of crop sequence berseem/maize + cowpea was 90.32 , while the lowest value was observed in crop sequence wheat/maize which was 63.64. Also, the value of cereal unit increased by $5.17 \%$ when maize was intercropped with cowpea compared with solid maize. These observations were due to the use of legume crops in rotation or intercropping and hence led to higher soil organic matter levels explain more fully or delete which led to higher yields compared with crop sequence wheat/maize. Similar results were obtained by Abou-Keriasha et al. (2012).

Preceding crop and intercropping effects on net return of intercropping maize with cowpea

Results in Table 9 reveal the values for total revenue and net return were affected by preceding crop and intercropping. The crop sequence wheat+fahl 
berseem/maize+cowpea recorded the highest for total revenue (16.0) and net return (9.4). While the crop sequence berseem/maize recorded the lowest total revenue (13.6) and net return (8.1). The crop sequence faba bean+onion/maize+ cowpea recorded the second rank in total revenue and net return. Also, intercropping maize with cowpea resulted in an increase of $3.4 \%$ in total revenue and $3.5 \%$ in net return compared with solid.

TABLE 9. Total revenue cost and net returns of each crop sequence (L.E.).

\begin{tabular}{|c|c|c|c|c|}
\hline \multicolumn{2}{|c|}{ Crop sequence } & \multirow{2}{*}{$\begin{array}{c}\text { Total } \\
\text { cost } \\
\text { (L.E.) }\end{array}$} & \multirow{2}{*}{$\begin{array}{c}\text { Total } \\
\text { revenue }\end{array}$} & \multirow[b]{2}{*}{ Net return } \\
\hline Preceding crop & $\begin{array}{l}\text { Cropping } \\
\text { system }\end{array}$ & & & \\
\hline \multirow{3}{*}{ Wheat } & Solid maize & 6.0 & 14.60 & 8.60 \\
\hline & $\begin{array}{ll}\text { Maize } \\
\text { cowpea }\end{array} \quad+$ & 6.1 & 15.15 & 9.05 \\
\hline & mean & 6.0 & 14.80 & 8.80 \\
\hline \multirow{3}{*}{ Wheat + faba bean } & Solid maize & 6.0 & 15.25 & 9.25 \\
\hline & $\begin{array}{l}\text { Maize } \\
\text { cowpea }\end{array}$ & 6.3 & 16.00 & 9.60 \\
\hline & mean & 6.1 & 15.50 & 9.40 \\
\hline \multirow{3}{*}{ Faba bean + onion } & Solid maize & 6.6 & 15.20 & 8.40 \\
\hline & $\begin{array}{l}\text { Maize } \\
\text { cowpea }\end{array} \quad+$ & 6.7 & 15.50 & 8.75 \\
\hline & mean & 6.6 & 15.30 & 8.70 \\
\hline \multirow{3}{*}{ Berseem } & Solid maize & 5.0 & 13.60 & 8.10 \\
\hline & $\begin{array}{l}\text { Maize } \\
\text { cowpea }\end{array}$ & 5.4 & 14.20 & 8.35 \\
\hline & mean & 5.2 & 14.00 & 8.20 \\
\hline \multirow[b]{2}{*}{ Mean of all crops } & solid & 5.9 & 14.70 & 8.60 \\
\hline & $\begin{array}{ll}\text { Maize } \\
\text { cowpea }\end{array} \quad+$ & 6.1 & 15.20 & 8.90 \\
\hline
\end{tabular}

7.0 L.E. $=1.0$ American dollars

Finally, it is concluded that the preceding legume crop had greatest effects on yield and yield components of maize, while intercropping maize with cowpea had greatest effect on weed density.

\section{References}

Abou-Keriasha, M.A., Zohry, A.A. and Haikle, M.A. (1998) Maize and soybean yields affected by preceding crops and crop rotation. J. Agric. Sc. Mansoura Univ. 23 (11), 4721-4728.

Abou-Keriasha, M.A., Abd El-Hady, M.A. and Nawar, F.R. (2009) Response of some cowpea varieties to intercropping with maize under upper Egypt condition. Egypt. J. Appl. Sci. 24(2B), 495-514.

Abou-Keriasha, M.A., Ibrahim, Sahar T. and Mohamed, E.E.A. (2011) Effect of cowpea intercropping date in maize and sorghum field on productivity and infestation weed. Egypt. J. Agron. 33 (1), 35-49.

Egypt. J. Agron. 35, No. 2 (2013) 
Abou-Keriasha, M.A., Mohamed, Wafaa Kh., Eisa, Nadia M. and Kamel, A.S. (2012) Intensive crop rotations to improve agricultural production in middle Egypt. Egypt. J. Agric. Res. 90 (4), 427 - 443.

Agricultural Statistics (2010) Summer and Nile crops Agriculture statistics and Economic Sector. Ministry of Agriculture and Land Reclamation, Egypt (2), 109.

Ahlawet, L.P.S., Singh, A. and Sara, F.C.S. (1981) Effected of winter legumes on the nitrogen economy and productivity of succeeding cereals. Exp. Agric. 12, 57- 62.

Brockhaus, V.L. (1962) “ $A B C$ der Landwirtschaft" partr $1,2^{\text {nd }}$ ed. VEB, Brockhaus Veriag, Leipzig, Germany, pp. $488-489$.

Chen, C.M., Cott, W., Neill, K., Wichman, D. and Knox, M. (2004) Row configuration and nitrogen application for barley- pea intercropping in Montana. Agron. J. 96, 1730-1738.

Fininsa, C. (1997) Effects of planting, relative planting date and inter-row spacing on a haricot bean/maize intercrop. African Crop Sci. J. 5 (1), 15-22.

Gregrich, E.C., Drury, C.F. and Baldock, J.A. (2001) Changes in soil carbon under long - term maize in monoculture and legume - based rotation. Can. J. Soil Sci. 81, 21-31.

Hollander, N.G., Bastiaans, L. and Kroff, M.J. (2007) Clover as a cover crop for weed suppression in an intercropping design. 1, characteristics of several clover species. Eure. J. Agron. 26 (2), 92-103.

Khan, S.M., Bhat, M.A., Qayoom, S., Shah, M.H. and Sidiggue, M. (2002) Performance of maize (Zea mays) and cowpea (Vigna unguiculata L.) intercropping under Kashmir conditions. Plant Archives, 2 (2), 229-231.

Liebman, M. and Dyck, E. (1993) Crop rotation and intercropping strategies for weed management. J. Appl. Ecol. 3, 92-122.

Mac Coll, D. (1991) Studies on maize (Zea mays L.) at bunda Malawi. 11: Yield in short rotation with legume. Exp. Agric. 25, 367 -374.

MSTATC (1980) A Micro computer program of design management and analysis of agronomic research experiments. Michigan State Univ., USA.

Shafshak, S.E., Salem, M.S., Salem, F.M. and Gelilah, G.Y. (1983) The role of crop rotation in controlling weeds and nematodes. 1- Effect of crop rotation on the spread of weeds. Proc. $1^{\text {st }}$ Conf. of Agron. Egypt, Scio Crop Sci. pp. 891-905.

Snedecor, G.W. and Cochran, W.G. (1988) "Statistical Methods". $7^{\text {th }}$ ed. Iowa State Univ. Press, Ames, Iowa, USA.

Willey, R.W. and Rao, M.R. (1980) Competitive ratio for quantifying competition between intercrops. Exp. Agric. 16, $117-125$. 
Willey, R.W. and Osira, S.O. (1972) Studies on mixture of maize and bean (Phasolus vulgaris) with particular reference to plant population. J. Agric. Sci., Camb. 79, $519-529$

Zohry, A.A. (2005) Effect of preceding winter crops and intercropping on yield, yield components and associated weeds in maize. Annals of Agric Sci., Moshtohor, 43(1), $139-148$.

Zougmore, R., Kambou, F.N., Ouattara, K. and Guillobez, Z.S. (2000) Sorghum cowpea intercropping effective technique against runoff and soil erosion in the sahel (Saria, Burkina Faso). Arid Soil Res. and Rehabitation, 14, 329-340

(Received 26/12/2013;

accepted $22 / 4 / 2014)$ 


\title{
فائدة المحصول البقولى فى الدورة والتحميل لزيادة الانتاجية

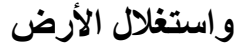

\author{
محمد أبو العيون مصطفى أبو كريشة ، نادية محمد أحمد عيسى و محمد مراد لملوم

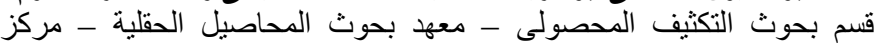 \\ البحوث الزر اعية - الجيزة - مصر.
}

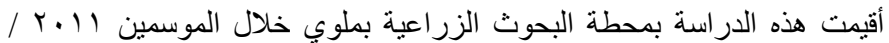

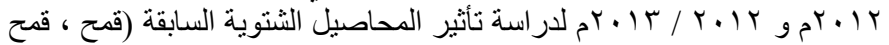

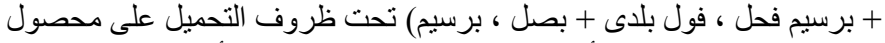

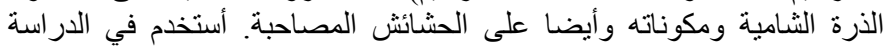
تصميم القطع المنشقة في ثلاث مكرراته وأثات

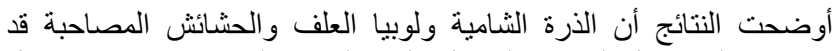

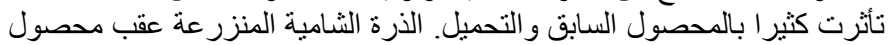

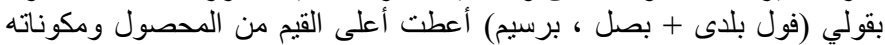

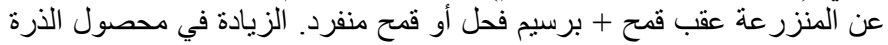

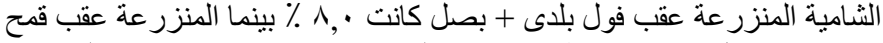

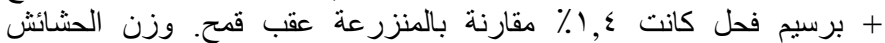

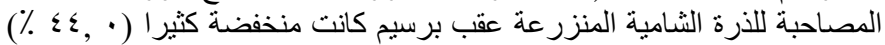

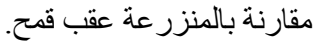

المحصول و مكوناته للذرة الثامية المحملة مع لوبيا العلف كانت عالية مقارنة

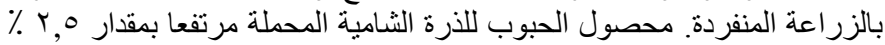

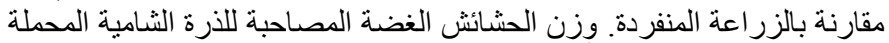

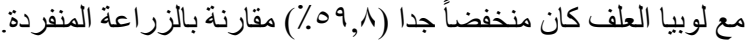

محصول لوبيا العلف المحملة مع الذرة الثامية أنخفض كثيرا ( , .7 \% ) .

أعلى قيمة من كفاءة استغلال الأرض ( LER ) لوحظ عندما لوندا كان المحصول

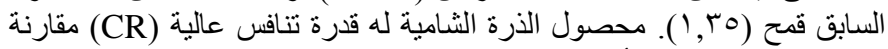

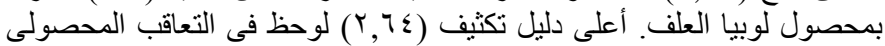

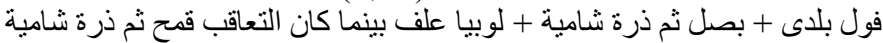

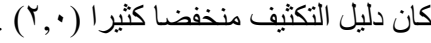

التعاقب المحصولى برسيم ثم ذرة شامية + لوبيا علف أعطى أعلى قيمة في في أعلى

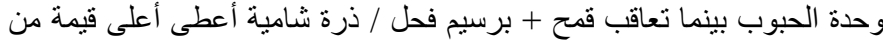

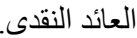

أخيرا، هذه الدراسة أوضحت أن تأثير المحاصيل البقولية السابقة للذرة

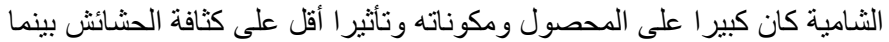

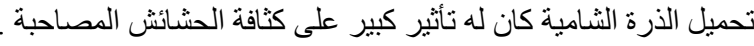

